First draft: June 12, 2009

This draft: June 29, 2009

\title{
INTERNATIONAL MONIES, SPECIAL DRAWING RIGHTS, AND SUPERNATIONAL MONEY
}

by

\author{
Pietro Alessandrini* and Michele Fratianni**
}

\begin{abstract}
$\underline{\text { Abstract }}$
The current international monetary system (IMS) is fragile because the dollar standard is rapidly deteriorating. The dual role the dollar as the dominant international money and national money cannot be easily reconciled because the US monetary authorities face a conflict between pursuing domestic objectives of employment and inflation and maintaining the international public good of a stable money. To strengthen the IMS, China has advocated the revitalization of the Special Drawing Rights (SDRs). But SDRs are neither money nor a claim on any international institution; are issued exogenously without any consideration to countries' financing needs; and can activate international monies only though bilateral transactions. The historical record of SDRs as international reserves is altogether unimpressive. We propose instead the creation of a supernational bank money (SBM) within the institutional setting of a clearing union. This union would be a full-fledged agreement by participating central banks on specific rules of the game, such as size and duration of overdrafts, designation of countries that would have to bear the burden of external adjustment, and coordination of monetary policies objectives and at expense of the maintenance of the international public good. We also discuss structural changes that would make SDRs converge to SBMs.
\end{abstract}

Key Words: international money, international monetary system, Special Drawing Right, supernational bank money.

JEL Classification: E42, E52, F33 and F36.

*Università Politecnica delle Marche, Department of Economics, Ancona (Italy), Email

p.alessandrini@univpm.it.

**Indiana University, Kelley School of Business, Bloomington, IN 47405 (USA) and Università

Politecnica delle Marche, Department of Economics, Ancona (Italy), Email fratiann@indiana.edu.

We thank Andrea Presbitero, Paolo Savona, and Alberto Zazzaro for comments and suggestions on an earlier draft of the paper. 


\section{Introduction}

The ongoing financial crisis has underscored the inherent fragility of the international financial system and of its regulatory structure. Originated in the United States, the country that enjoys the most advanced financial markets and is also at the center of the international monetary system (IMS), the crisis was preceded by a bubble in the housing and share markets fuelled by an expansive monetary policy; see Fratianni (2008). By now, a consensus has developed that the financial regulatory structure needs a significant overhaul. Much less attention has instead received the instability of the dollar-based IMS and the potential that it may have in sparking another deep crisis in the future. The fact that the financial tsunami has not instigated a confidence crisis in the US dollar has fed optimism that the financial crisis may be resolved without substantive changes in the existing international monetary regime. In this vein, at the onset of the crisis, Bernanke (2007) re-affirmed the thesis that the external imbalances of the United States were largely caused by factors taking place outside the United States, namely in fast growing emerging economies (in particular China) and oil-producing countries where exante saving was far in excess of ex-ante investment. The implication of the global saving glut thesis is that the large US external imbalances are largely a temporary phenomenon, rather than structural, and thus would find a natural solution in time. Another implication of the Bernanke thesis is that the onus of the adjustment problem falls on the periphery rather than on the center country of the dollar-based IMS.

The global saving glut hypothesis diverts attention from the long-term deterioration of the dollar standard. The external deficits of the United States, with the attendant dramatic rise in its net foreign indebtedness, are long dated and result from a fundamental weakness of an IMS 
where a single national money functions also as an international money, a point that was first identified by Robert Triffin (1960) in the context of the gold-dollar exchange standard.

With this premise, the paper argues that the current IMS is fragile because the dollar standard is deteriorating. The dollar remains at the top of the money pyramid because none of the competing international monies, and especially the euro, is ready yet to fully replace the dollar. This scenario is reminiscent of what took place in the inter-war period when sterling was today's dollar and the dollar was an emerging international money. The long transition from one leading international money to another did not serve us well: it instigated a dark age of protectionism and contributed to the severity of the Great Depression; see Kindleberger (1973). Like the dollar, the French franc and the German mark in the Thirties, today's euro and currencies of large creditor countries (such as China's yuan) are not ready to take up the money leadership. This historical parallel should give policy makers sufficient incentives to shore up quickly the IMS. Changes have to be fundamental. To begin with, we must recognize that money and finance are closely intertwined; it is wishful to think that IMS robustness will come by concentrating exclusively in "fixing" the financial system. The IMS itself needs to be fixed and the best time for doing it is now for the simple reason that radical changes in the rules of the game are effected in times of crises.

Our preferred solution is the creation of a supernational bank money (SBM), which would coexist along side with international monies. We take inspiration from the principles underlying Keynes’ old plan for bancor and an international clearing union; see Alessandrini and Fratianni (2009). These principles tend to resurface in times of stress. Recently, Zhou Xiaochuan (2009), the governor of the People's Bank of China, has made the case for a restructuring of the IMS around a supernational money, but for practical reasons has then opted 
for the revitalization of the Special Drawing Rights (SDR). This has found a policy echo in the recommendation of the G20 leaders, at the London April, 2009 meeting, to produce a fresh allocation of $\$ 250$ billion of SDRs. We argue that dropping more SDRs from a helicopter, without changing the essential characteristics of SDRs, is not a long-term solution. SDRs suffer from two fundamental drawbacks: they are neither money nor a claim on any international institution. The historical record indicates that the SDRs have failed in their intended role as supplement to international reserves. Significant structural changes have to be introduced to make the SDRs work.

The paper is organized as follows. Section II presents a few historical facts about international monies; we emphasize that the money structure tends to be more hierarchical than hegemonic and that the transition period from one dominant money to another is long. Section III keys on the fundamental weakness of an international money that is also a national money; there we present data on the long-term deterioration of the dollar standard and raise the issue of how long can the United States continue to borrow foreign capital without paying a sovereignrisk premium. Section IV details the limitations of the SDR scheme. Section V elaborates on our SBM plan. Conclusions are drawn in Section VI.

\section{International monies}

The historical evidence indicates that one currency tends to dominate others both as an international medium of exchange and as a store of value. In the $19^{\text {th }}$ century, Britain was the leading industrial economy in the world and its currency, the British pound, the leading but not 
the exclusive international money in the world. ${ }^{1}$ The IMS was more hierarchical than hegemonic (Fratianni and Hauskrecht 1998). Britain was at the top the pyramid in the international gold standard. Interest rate changes initiated in the periphery prompted a smaller reaction in British interest rates than in the interest rates of the two countries that immediately followed Britain in the hierarchy, France and Germany (Lindert 1969, pp. 49-52). ${ }^{2}$

World War I marked the end of Britain’s economic and financial leadership; yet, the key status of the pound lasted for more than four more decades (Eichengreen 2005). The inter-war period left a vacuum in both currency and trade (Kindleberger 1973).The Bretton Woods Agreement of 1944 sanctified the preeminence of the US dollar. The Agreement broke down in 1973, but in practice as early as 1968 (when the German Bundesbank decided to revalue the

\footnotetext{
${ }^{1}$ Further back in history, the Roman silver denarius was the first world currency; the Byzantine solidus was the unchallenged coin from the 5th to the 7th century; Roberto Lopez (1951) calls it the dollar of the Middle Ages. But the international role of the solidus was challenged by the Islamic dinar which eventually made the cross over; both lasted until the $12^{\text {th }}$ century. In the $13^{\text {th }}$ century, the Italian coins came to prominence: the Genoese genoino, the Florentine fiorino, and the Venetian ducato. All three coins circulated side by side for quite some time and shared three attributes: large weight (high unitary value), high intrinsic (purchasing power) stability and a leading position in international commerce of the issuer; see Cipolla (1956).

2 For more evidence on the center vs. periphery of the international gold standard, see Eichengreen (1985) and Flandreau et al. (1998). The pyramidal structure is also corroborated by reserve currency shares data on foreign holdings of major currencies (Lindert 1969, Tables 2 and 3). In 1899, foreign-exchange assets at official institutions denominated in pounds represented 63 percent of the total, those denominated in French francs 16 percent, and those denominated in marks 15 percent. These shares were computed by subtracting the "unallocated" item from the total in “official institutions” from Lindert's Table 3. In 1913, the reserve currency shares in pounds, francs and marks had become, respectively, 48 percent, 31 percent and 15 percent. Quoting from Lindert (1969, p. 25):

"One trend revealed by these benchmark data is the relative rise of France and Germany as reserve centers. London was easily the chief repository for official funds at the turn of the century...The subsequent competition among centers implied by the available statistics was more real in the case of Anglo-German competition than Anglo-French. The lion's share of French liabilities to foreign central banks and governments after the turn of the century was taken by the official franc balances of Russia alone, while the use of marks as reserves was more widespread...”
} 
Deutsche mark relative to the dollar), because the United States "abused" the privileges emanating from its national currency functioning also as the key international currency.

The creation of the European Monetary Union (EMU) in 1999 consolidated 11 separate currencies of industrialized countries into a brand new currency, the euro. It was a big event that, on balance, was greeted more with optimism than pessimism about the prospects of the euro to challenge the dollar in the market place for international monies. ${ }^{3}$ Ten years later, the performance of the euro as an international money has not disappointed the euro enthusiasts. The ascendancy of the euro as an "international store of value" coincides with the increased degree of efficiency, liquidity and integration of the euro financial markets.

Following the depreciation of the dollar relative to the euro starting in 2002, increasing attention has been given to the prospect that central banks, especially those in Asia, may want to substantially diversify their holdings out of dollars and into euros and, in the process, bring an end to the dominance of the dollar in official portfolios. Data on currency composition of foreign official holdings, available up to 2007, show that the dollar retains the same reserve share that prevailed at the end of Bretton Woods; see Table 1. The novel aspect in the data is that the euro has gained at the expense of currencies other than the dollar: the euro share in official reserves has gone from $6.7 \%$ of the combined shares of the legacy currencies mark, franc, and guilder in 1973 to $26.5 \%$ in 2007 . The euro has become an alternative to the dollar to the point that we may characterize the present system as the beginning of a bipolar international money system; see Fratianni and Hauskrecht (1998).

\footnotetext{
${ }^{3}$ Among euro enthusiasts, we mention, among others, Bergsten (1997), Alogoskoufis and Portes (1997), and Portes and Rey (1998); among euro pessimists, the clearest argument was made by Feldstein (1997) ; on this, see Fratianni et al. (1998). See also Papaioannou and Portes (2008) on the costs and benefits for the euro as an international currency.
} 
Table 1: Shares of national currencies in foreign official reserves (percent)

$\begin{array}{ccccccccc}\text { Year } & \text { US\$ } & \begin{array}{c}\text { Deutsche } \\ \text { mark }\end{array} & \text { Yen } & \begin{array}{c}\text { British } \\ \text { pound }\end{array} & \begin{array}{c}\text { French } \\ \text { franc }\end{array} & \begin{array}{c}\text { Swiss. } \\ \text { franc }\end{array} & \begin{array}{c}\text { NL } \\ \text { guilder }\end{array} & \text { Euro } \\ 1965 & 56.1 & 0.1 & 0 & 20 & 0.9 & 0 & 0 & \mathrm{Na} \\ 1973 & 64.5 & 5.5 & 0.1 & 4.2 & 0.7 & 1.1 & 0.5 & \mathrm{Na} \\ 1977 & 79.2 & 9.3 & 2.2 & 1.6 & 1.1 & 1.9 & 0.7 & \mathrm{Na} \\ 1982 & 57.9 & 11.6 & 4.1 & 1.8 & 1 & 2.3 & 1 & \mathrm{Na} \\ 1987 & 53.9 & 13.8 & 6.8 & 1.9 & 0.9 & 1.7 & 1.2 & \mathrm{Na} \\ 1992 & 48.9 & 14 & 7.4 & 2.6 & 2.6 & 0.8 & 0.7 & \mathrm{Na} \\ 1997 & 59.1 & 13.7 & 5.1 & 3.3 & 1.5 & 0.5 & 0.5 & \mathrm{Na} \\ 2003 & 65.9 & \mathrm{Na} & 3.9 & 2.8 & \mathrm{Na} & 0.2 & \mathrm{Na} & 25.2 \\ 2004 & 65.9 & \mathrm{Na} & 3.8 & 3.4 & \mathrm{Na} & 0.2 & \mathrm{Na} & 24.8 \\ 2005 & 66.9 & \mathrm{Na} & 3.6 & 3.6 & \mathrm{Na} & 0.1 & \mathrm{Na} & 24.1 \\ 2006 & 65.5 & \mathrm{Na} & 3.1 & 4.4 & \mathrm{Na} & 0.2 & \mathrm{Na} & 25.1 \\ 2007 & 63.9 & \mathrm{Na} & 2.9 & 4.7 & \mathrm{Na} & 0.2 & \mathrm{Na} & 26.5\end{array}$

Source: Chinn and Frankel (2005, Table 1) for data up to 1997 and IMF, 2008 Annual Report for the period 2003-2007.

The status of international monies is rapidly evolving and the end point will be determined by future and thus uncertain policy actions. To see this point, we recall that, other things the same, there is a positive correlation between the relative economic size of the country and its international-currency status. The decline in the dollar share of world reserves after World War II occurred as the U.S. share of world output was falling (Eichengreen and Frankel 1996). Relative economic size may proxy for the relative transaction domain of the currency; as this shrinks so does the network value of that currency. On this score, the formation of EMU gave the euro a big push in competing against the dollar for the position of dominant currency. On the other hand, the euro had to overcome the serious handicap that it was issued by a new and 
untested central bank, the European Central Bank (ECB), representing a group of countries that had yet to achieve political unification. While the ECB is now a tested institution that has earned a considerable amount of reputation as inflation fighter, political unification in the EMU is not on the horizon. Without political unification, the euro project will remain incomplete and so will the challenge of the euro to the preeminence of the dollar.

In sum, the dollar remains the leading international currency, but with the ascent of the euro the system is becoming increasingly bipolar. As we will argue in Section V, a bipolar structure world could be exploited to create a supernational money, based on the foundations of the two international monies and a clearing mechanism.

\section{The long-term deterioration of the dollar standard}

The inherent flaw in using an international money that is also a national money is that the issuing country faces a conflict between pursuing domestic objectives of employment and inflation and maintaining the international public good of a stable money. There are circumstances in which the twin objectives cannot be reconciled simultaneously and a choice must be made as to which objective dominates. In the post World War II era -- with complete suffrage and a political system more reactive to pressure groups-conflicts between domestic and external objectives tend to be resolved in favor of the former, except when the external constraint is really binding. This has been particularly true for the United States, which has enjoyed a soft external constraint. The costs of being a reserve currency country were perceived to be too large relative to the benefits; the United States generated an inflation rate that was neither consistent with the fixed dollar-gold conversion price nor with the preferences of major players like Germany. 
The dollar standard has been deteriorating over the last three decades as a result of the US economy systematically spending beyond its domestic output and becoming, in the process, the largest net debtor in the world. Table 2 presents data on the US current account balance -which captures the difference of the excess of domestic absorption over domestic output- from 1973 to 2007, both in billions of dollars and as a percent of US GDP. To emphasize trends, we consider periods of at least five years. From the end of Bretton Woods to 2007, the US has accumulated deficits of \$ 6,665 billion at an average yearly rate of 2.1 percent of US GDP. More importantly, external deficits have been rising over time: from virtual balance of the Seventies to yearly deficits averaging 1.8 of GDP in the Eighties, 1.9 percent of GDP in the Nineties, and 5.1 percent of GDP in the most recent period of 2001-2007.

Table 2: US current account balance, 1973 -2007

\begin{tabular}{|c|c|c|}
\hline Period & $\begin{array}{l}\text { Cumulative surplus } \\
(+) \text { or deficits }(-) \text {, } \\
\text { billions of dollars }\end{array}$ & $\begin{array}{l}\text { As a percent of } \\
\text { US GDP, } \\
\text { annual average }\end{array}$ \\
\hline 1973-1980 & 4.1 & 0.1 \\
\hline 1981-1985 & -251.7 & -1.3 \\
\hline 1986-1990 & -607.4 & -2.4 \\
\hline 1991-1995 & -367.2 & -1.1 \\
\hline $1996-2000$ & $-1,199.6$ & -2.7 \\
\hline 2001-2007 & -4.242 .7 & -5.1 \\
\hline 1973-2007 & $-6,664.5$ & -2.1 \\
\hline
\end{tabular}

Source: For the US current account balance, Economic Report of the President: 2009 Report Spreadsheet Tables; for US GDP, FRED data base, Federal Reserve Bank of St. Louis.

Table 3 shows data in the net international investment position of the United States, with direct investment measured at current cost. Net foreign debt at the end of 2007 was $\$ 2,442$ 
billion. Over the $21^{\text {st }}$ century this debt has increased by $\$ 1,111$ billion, far less than the cumulative current-account deficits of $\$ 4,243$ billion. The reason for this remarkable discrepancy between the sum of deficit flows and changes in net foreign debt is due to the international role of the dollar, which permits the United States, not only to earn foreign seigniorage, but to act as the "banker of the world" in the language of Despres, Kindleberger, and Salant (1966). That is, the United States borrows short at relative low rates of interest and lends long at high rates of return. The banker-to-the-world analogy can be extended into a modern leveraged-financialintermediary view, as in Gourinchas and Rey (2005). Under this scenario, the United States is issuing not only short-term liabilities but also fixed-income liabilities that are leveraged to effect investments abroad in the form of illiquid, but with high capital gain potential, foreign direct investments and equities. The excess rates of return on U.S. assets over U.S. liabilities captures the "exorbitant privilege" the United States earns because of its special role in the international monetary system.

The data of Table 3 are consistent with the "exorbitant privilege" thesis of the dollar. Over the period 2001-2007, the United States enjoyed an excess of foreign price appreciation on its foreign assets over price appreciation on foreign holdings of US assets valued at $\$ 1,263$ billion; an exchange rate adjustment, due to the depreciation of the dollar relative to the foreign currencies that denominate US foreign assets, worth $\$ 950$ billion; and higher valuation, due to changes in coverage and capital gains on direct investment affiliates, valued at $\$ 956$ billion. The end result is that the increase in net foreign debt, over the 2001-2007 period, was approximately one-fourth of the cumulative current-account deficits. 
Table 3: Components of Changes in the Net International Investment Position

With Direct Investment at Current Cost, 1989-2007

[Millions of dollars]

\begin{tabular}{|c|c|c|c|c|c|c|c|}
\hline \multirow[b]{4}{*}{ Year } & \multirow{4}{*}{$\begin{array}{l}\text { Position } \\
\text { Beginning }\end{array}$} & \multicolumn{5}{|c|}{ Changes in position } & \multirow{4}{*}{$\begin{array}{c}\text { Position } \\
\text { Ending }\end{array}$} \\
\hline & & \multirow[b]{3}{*}{$\begin{array}{l}\text { Financial } \\
\text { flows }\end{array}$} & \multicolumn{3}{|c|}{ Attributable to } & \multirow[b]{3}{*}{ Total } & \\
\hline & & & \multicolumn{3}{|c|}{ Valuation adjustments } & & \\
\hline & & & $\begin{array}{c}\text { Price } \\
\text { changes } \\
\text { (b) }\end{array}$ & $\begin{array}{c}\text { Exchange- } \\
\text { rate } \\
\text { changes }{ }^{1} \\
\text { (c) }\end{array}$ & $\begin{array}{c}\text { Other } \\
\text { changes }^{2} \\
\text { (d) }\end{array}$ & & \\
\hline 1989 & $-160,865$ & $-47,394$ & $-38,017$ & $-5,747$ & 12,230 & $-78,928$ & $-239,793$ \\
\hline 1990 & $-239,793$ & $-58,123$ & $-26,636$ & 43,845 & 57,302 & 16,388 & $-223,405$ \\
\hline 1991 & $-223,405$ & $-43,833$ & $-63,179$ & 4,272 & 41,399 & $-61,341$ & $-284,746$ \\
\hline 1992 & $-284,746$ & $-93,939$ & $-39,673$ & $-54,691$ & 68,765 & $-119,538$ & $-404,284$ \\
\hline 1993 & $-404,284$ & $-79,208$ & 109,707 & $-14,462$ & 110,517 & 126,554 & $-277,730$ \\
\hline 1994 & $-277,730$ & $-124,237$ & 39,636 & 45,741 & 25,285 & $-13,575$ & $-291,305$ \\
\hline 1995 & $-291,305$ & $-82,838$ & $-93,308$ & 17,221 & 27,319 & $-131,606$ & $-422,911$ \\
\hline 1996 & $-422,911$ & $-134,476$ & 47,359 & $-42,287$ & 96,022 & $-33,382$ & $-456,293$ \\
\hline 1997 & $-456,293$ & $-218,977$ & $-44,200$ & $-140,151$ & 80,058 & $-323,270$ & $-779,563$ \\
\hline 1998 & $-779,563$ & $-66,965$ & $-148,130$ & 31,100 & 112,094 & $-71,901$ & $-851,464$ \\
\hline 1999 & $-851,464$ & $-238,148$ & 220,818 & $-36,392$ & 180,843 & 127,121 & $-724,343$ \\
\hline 2000 & $-724,343$ & $-477,701$ & 12,299 & $-199,581$ & 58,696 & $-606,287$ & $-1,330,630$ \\
\hline 2001 & $-1,330,630$ & $-400,254$ & $-116,115$ & $-111,724$ & 89,848 & $-538,245$ & $-1,868,875$ \\
\hline 2002 & $-1,868,875$ & $-500,515$ & $-62,273$ & 148,321 & 245,372 & $-169,095$ & $-2,037,970$ \\
\hline 2003 & $-2,037,970$ & $-532,879$ & 8,613 & 275,116 & 200,607 & $-48,543$ & $-2,086,513$ \\
\hline 2004 & $-2,086,513$ & $-532,331$ & 94,578 & 197,843 & 81,006 & $-158,904$ & $-2,245,417$ \\
\hline 2005 & $-2,245,417$ & $-700,716$ & 720,816 & $-220,947$ & 521,118 & 320,271 & $-1,925,146$ \\
\hline 2006 & $-1,925,146$ & $-839,074$ & 419,978 & 222,368 & $-103,930$ & $-300,658$ & $-2,225,804$ \\
\hline 2007 & $-2,225,804$ & $-774,345$ & 197,683 & 438,711 & $-78,074$ & $-216,025$ & $-2,441,829$ \\
\hline
\end{tabular}

Source: Bureau of Economic Analysis, International Economic Accounts, http://www.bea.gov/international/ 
The "exorbitant privilege" extracted by the United States because of the special role of the dollar translates into a soft external constraint. Unlike any other country in the world, the United States can finance a significant amount of its imports of goods and services plus income payments through increases of low-interest rate liquid liabilities (primarily short-term US government securities and deposits with U.S. banks) held by foreign monetary authorities. For almost half a century, foreign central banks financing has accounted, on average, for approximately 6.5 per cent of total US imports, but have been higher when the dollar has been weak against major currencies and lower when the dollar has been strong; see Alessandrini and Fratianni (2009, Figure 1). Central bank financing ratios rose up to 40 per cent in the first half of the seventies in concomitance with the end of Bretton Woods and the first oil shock; declined to less than one per cent as the dollar experienced a sizeable appreciation in the first half of the eighties; rose again with the depreciation of the dollar after 1985; and settled to an average of 4 per cent in the nineties. Over the recent 2001-2008 period, the financing ratios have rise again to an average in excess of 12 percent of total imports, peaking at 19 percent in 2004; see Figure 1. In absolute numbers, over the eight-year span the stock of central bank financing rose by \$2,399 billion, according to US balance of payments statistics. 


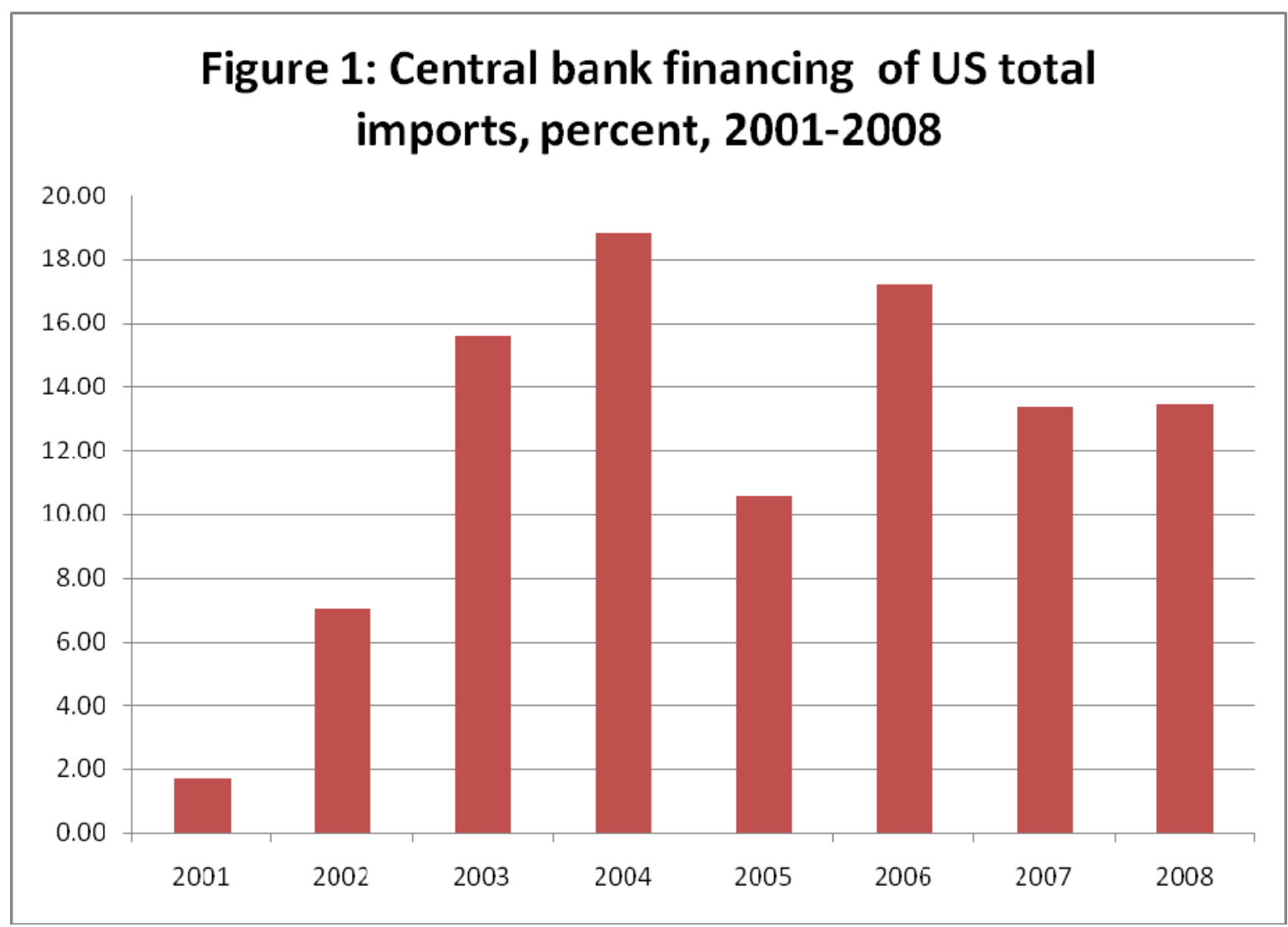

Source: Bureau of Economic Analysis, International Economic Accounts, http://www.bea.gov/international/

These trends reflect the propensity of many emerging economies, especially in Asia, and oil-producing countries to set undervalued exchange rates with respect to the dollar and to accumulate foreign reserves; see Dooley, Folkerts-Landau and Garber (2003) and Alessandrini and Fratianni (2009). This propensity, as we have seen, has risen since the start of the new millennium and has financed a growing share of US current-account deficits. International reserves have been growing at an average annual rate of 11 per cent over the period from 1995 to mid 2007, with a sharp acceleration taking place since 2003 when China began increasing 
sharply its stock of international reserves. ${ }^{4}$ China alone holds 15 per cent of US Treasuries and is concerned about its undiversified position. Russia, with the third largest stock of international reserves, has instead diversified significantly away from the dollar. ${ }^{5}$ On the other hand, the US government is relying increasingly on foreign official agencies to fund its current and prospective budget requirements. $^{6}$

In sum, foreign ownership of the US government debt, especially in the hands of few central banks raises the risk of a precipitous fall in the value of the dollar following a readjustment in the currency composition of international reserves. The critical question asked in the market is: How long can the United States continue to borrow foreign capital at existing rates without incurring in a sovereign-risk crisis?

The relative indifference of US policy makers towards balance-of-payments deficits and, later, about the value of the dollar in relation to other important currencies became known as "benign neglect.” A resurgence of this policy has occurred in the middle of this decade and is known as the saving glut hypothesis; see Bernanke (2005). According to this view, an exogenous upward shift of the saving functions in fast-growing Asian and oil-producing economies, unmatched by a comparable shift in their investment functions, was the cause of the large US

${ }^{4}$ At the end of 2002, Chinese reserves were $\$ 286$ billion; two years later they more than doubled to $\$ 610$ billion; two years later they almost doubled again to \$1066 billion; in 2009 they exceed \$ 2,000 billion, 75 percent of which dollar denominated; see China's Foreign Assets, Center for Geoeconomic Studies, http://blogs.cfr.org/geographics/2009/05/15/china\%E2\%80\%99s-foreign-assets/.

${ }^{5}$ The Moscow Times of May 19, 20009 reports that the euro share of Russia's foreign reserves, at the end of 2008, was 47.5 percent against the 41.5 share of the dollar; see. http://www.themoscowtimes.com/article/600/42/377235.htm.

${ }^{6}$ In the 2001-2007 period, foreign official holdings of US government securities rose by $\$ 1,746$ billion, an amount that is about 50 percent higher than the increase in net foreign debt. In 2008, central banks and sovereign funds purchased close to $\$ 600$ billion of Treasuries (see Brad Setser's "Who bought all the Treasuries the US issued in 2008? And who will be the big buyers in 2009?," http://blogs.cfr.org/setser/2009/). The 2009 fiscal stimulus of about \$ 800 billion will add further pressure on the US government borrowing requirements and likewise on efforts to diversify out of dollars. 
capital inflows since the middle of the nineties. The resulting ex-ante gap between saving and investment is responsible for current-account surpluses in emerging countries and falling real rates of interest in the world. According to the saving glut hypothesis, the industrial world, but primarily the United States, had to absorb the capital inflows generated by Asia and oilproducing countries. Once the shock peters out, current-account imbalances will be reduced. As we have already indicated in the introduction, the implication of the Bernanke thesis is that the onus of the adjustment problem falls on the periphery rather than on the center country of the dollar-based IMS; in others words, the appropriate US policy is benign neglect.

In sum, a national money that becomes an international money cannot serve two masters equally well. In the tug of war between domestic and international objectives, political economy considerations dictate that domestic goals of employment and inflation tend to win at the expense of the maintenance of the international public good. It follows that an effective reform of the international monetary must resolve the dual role of domestic/international money. At the moment, policy makers are betting on resuscitating the SDRs, the theme of the next section.

\section{THE SPECIAL DRAWING RIGHTS}

SDRs were created by the International Monetary Fund (IMF) in 1969 to supplement the stock of official reserves. The original intent of the program was to revitalize the dying Bretton Woods system by altering the composition of international reserves between the scarce quantity of monetary gold and the abundant stock of dollar liabilities. The initial allocation of SDR 9.3 billion, over the 1970-72 period, failed to achieve this objective. Not surprisingly, in 1971 the gold convertibility of the dollar was suspended. A second allocation of SDR 21.4 billion took 
place from 1979 tom 1981 in the wake of the second oil shock. Also this allocation failed to achieve the intended results of stabilizing the dollar-based IMS. After that, SDRs have played a marginal role as international reserve, in parallel with the declining importance of the IMF. The SDR has remained mainly a unit of account, defined in terms of fixed, but adjustable every five years, quantities of a few important national monies. At the moment, the basket includes the dollar, the euro, the yen and pound sterling.

The G20 recommendation of a new SDR allocation worth \$ 250 billion at the 2009 London meeting has brought back to front stage the SDR as an international reserve asset. It is the only official proposal to strengthen the IMS; hence, it deserves careful examination not only for its own merit but also for the prospect of a positive evolution of the IMS. Policy makers have underscored that the new allocation can be effected rapidly because it is part of an existing institution codified by the Articles of Agreement of the IMF. They have also claimed that the decision would create sufficient new international liquidity to finance external imbalances and set the IMF again back at the center of the IMS. In fact, the London recommendation builds on a weak scheme that has produced few results in the past. ${ }^{7}$ Furthermore, the size of the new allocation is small relative to the size of the external imbalances, especially those of the United States. Finally, the very structure of the SDRs assigns to the IMF a largely passive role.

To better understand the discrepancy between policy makers' expectations and likely outcome, we start by recalling that the "SDR is neither a currency, nor a claim on the IMF. Rather, it is a potential claim on the freely usable currencies of IMF members” (IMF 2009). Once a SDR allocation decision has been made, the IMF has no discretionary power on how SDRs will be used. Under the present system, exchanges of SDRs for national currencies occur

\footnotetext{
${ }^{7}$ Fratianni and Savona (1974) formally demonstrated the intrinsic weakness of the SDR scheme, which the authors define as "a classic jump in the dark". See also Fratianni (1974).
} 
either through voluntary bilateral transactions or through the IMF that may designate member countries with external surpluses to accept SDRs in exchange for their currencies. Thus, the IMF acts as a broker matching deficit to surplus countries to exchange SDRs for international monies. The transactions remain bilateral.

Each member country receives an amount of SDRs that is proportional to its quota in the Fund, without any necessary ex-ante consideration about the external liquidity of the country. After the allocation, a deficit country (DC) can swap SDRs for an equivalent amount of international money, say dollars, at a surplus country (SC). The price of the swap is an interest rate (equal to a weighted average of the money market of the four currencies in the SDR basket) paid by DC to SC. After the swap, DC has more dollars and less SDRs; the opposite is true for SC. DC can use the acquired dollars to intervene in the exchange markets, while SC can use the acquired SDRs to diversify the currency composition of its international reserves. In essence, the mechanics are those of a "giro system” aimed at stabilizing exchange rates (Machlup 1968, p. 13).

The SDR scheme is designed to activate hoarded international money. The latter is redistributed from SC to DC countries. But there is very little that SDRs can do to improve the position of the largest deficit and net external debtor country in the world. The United States is unique in both the size of its external imbalances and as a provider of the dominant international money. The US share of the new SDR 250 billion is paltry relative to the size of the US external imbalance. To make a dent on the problem would require a large allocation only for the United States. Under such circumstances, the Fed could exchange SDRs for dollar assets at SCs, starting from the dollar-rich People’s Bank of China, and reduce the high weight of dollars in 
official reserves. ${ }^{8}$ But apart from the large size of SDRs involved, the bilateral SDR-dollar swap would be incapable of making the necessary adjustment required to mop up the "excess" supply of dollars. The swap, in fact, would leave the size of the US monetary base unchanged (only the composition would change in favor of domestic assets). To effect a reduction of the US monetary base, the Fed would have to sell in the market place the T-bills received from SCs in exchange of SDRs. The Fed and the US government would have to explicitly agree to such a policy.

The basic idea of using SDRs as a replacement for dollar-denominated assets held by central banks was taken up in the Seventies by the Committee of Twenty (1974). The latter produced a proposal, known as the Substitution Account, which was later evaluated by the Interim Committee of the IMF in 1978-79; see Kenen (1981) and Micossi and Saccomanni (1981). Under the proposal, central banks could open an account denominated in SDRs by depositing dollar assets at the IMF. Thus, SDRs would be created endogenously by the actions of those central banks that deemed to have too many dollar assets in their official reserves. In contrast, the existing SDR scheme envisions only exogenous supply increases. The Substitution Account never came to light because neither the IMF nor the United States were willing to bear the exchange rate risk arising from an unhedged position of the Fund having dollar assets and SDR liabilities (Boughton 2001, ch. 18). Had the Substitution Account been implemented, we would have avoided the large overhang of dollar reserves that now threatens the durability of the international dollar standard.

The importance of reforming the existing SDR mechanism in a supernational direction has been raised recently by Zhou Xiaochuan (2009), the Governor of the People's Bank of

\footnotetext{
${ }^{8}$ In the balance sheet of the Fed, the exchange would imply a reduction of SDRs and an equivalent increase of dollar assets (T-bills).
} 
China. China, more than any other country, is exposed to the risk of an implosion of the dollar standard and feels urgently the need to diversify out of dollar assets. Given that the yuan is not an international money, there is an obvious Chinese interest in seeing the transformation of the dollar standard into a supernational money standard. As we have mentioned it in the introduction, Mr. Xiaochuan has chosen to endorse the SDRs and has suggested at the same time a series of recommendations that would make them converge progressively to a supernational money. Among the recommendations, it is worth mentioning the following three: transforming the SDR from an artificial basket currency into one backed by assets; establishing a settlement system between the SDR and national currencies so as to make the SDR a fully fledged money; and linking the SDRs to a specific institution that would be responsible for their management and their value, in other words becoming someone’s liability.

\section{SUPERNATIONAL BANK MONEY}

The current, deep, financial crisis creates almost a unique opportunity for a gradual introduction of a supernational money aimed at reducing the asymmetries of the key-currency system. The natural reference for this gradual approach is European monetary unification. Before unification, the European Currency Unit (ECU) was as much an artificial currency as the SDR is today. Actual transactions and assets denominated in ECU represented a small share of the market. ECU was no one's liability. The big change occurred when the ECU became the euro issued by a supernational central bank with a clear mandate for price stability. Something similar must occur at the world level before SDR can become a true supernational money. But the experience of European monetary unification indicates that the objective of economic convergence between member countries is a precondition that at the world level appears 
economically and politically insurmountable. One world money governed by a world central bank is utopian and also difficult to justify in economic terms. A single monetary policy applied to vastly heterogeneous countries amplifies divergences between countries with different levels of development. There is no other feasible solution to the coexistence between supernational money and key-currencies.

The alternative to a politically unfeasible autonomous superanational central bank is to create a cooperative agreement among a restricted group of key countries that find it in their interest to share responsibility to stabilize the IMS. Theory and practice suggests that cooperation is more likely the smaller the number of and the more homogeneous are the participating countries.

Our proposal to reform the IMS is based on a cooperative agreement among a restricted group of key countries that find it in their interest to stabilize the IMS (Alessandrini and Fratianni 2009). The Fed and the ECB, the two most important central banks with an antiinflation reputation, could take the initiative by establishing at the IMF a multilateral clearing system of debit and credit entries restricted to central banks. The first step would involve the Fed and the ECB transferring to the clearing institution earning assets denominated in dollars and euros, respectively, against an equivalent amount of supernational bank money or SBMs. SBMs would have the property of a basket currency with the attendant risk diversifying characteristics. The mechanics of the SBM would be similar to the SDR with a very critical difference: SBMs, unlike SDRs, would be a liability of a supernational institution. Unlike SDRs, SBM would become supernational money for central banks.

The clearing system would be a big step forward from the SDR system in two fundamental ways. The first is that SBMs would be created endogenously as a result of actions 
taken by participating countries, whereas SDRs are created exogenously as a sort of international helicopter money. The second is that the clearing system operates on a banking principle. The settlement of credit and debit between central banks would occur through their SBM accounts: DC central banks would reduce their stock of SBMs, while SC central banks would increase their stock. In addition to redistributing SBMs, the clearing institution could create them through an overdraft facility, the size of which would have to be agreed ex-ante by the participating countries. DCs could activate their overdraft facility on their SBM accounts and become net debtors vis-à-vis the clearing institution. Unlike the SDR scheme, each country would have a credit or debit position vis-à-vis the clearing institution; that is, the payment structure would be multilateral rather than bilateral.

The clearing proposal draws from five principles used by Keynes in his plan to reform the international monetary system at the end of World War II: gradualism, banking approach, complementarity, multilateralism, and symmetry of adjustment (Alessandrini and Fratianni 2009). ${ }^{9}$ The clearing system would solve the impasse that impeded the adoption of the Substitution Account in the Seventies. In the clearing system, the IMF does not bear exchange rate risk because it does not hold open positions in assets denominated in national currencies. A SC central bank exchanges SBMs for dollar reserves by first selling dollar assets in the open market and then by converting dollar deposits at the Fed in SBM deposits at the clearing institution. The monetary base of the Fed would fully reflect the conversion of SBMs for dollar assets. The automatic sterilization permitting the United States to insulate its monetary base from the effects of external deficits would disappear. By having to align the monetary base to net

\footnotetext{
${ }^{9}$ The denomination SBM was used by Keynes in the Treatise on Money (1930, p.358): "Its assets should consist of gold, securities and advances to central banks, and its liabilities of deposits by central banks. Such deposits we will call supernational bank money (or S.B.M for short)”. Excluding gold, our approach is the same.
} 
foreign payments, the "exorbitant privilege” of the United States as a key-currency country would cease. Clearly, the Fed would have to accept such a mechanism.

The clearing system could not work without explicit rules of the game, such as the size of the overdraft facility, the terms of repayment of the overdraft, and who bears the burden of external adjustment. In an inflationary environment, it would be up to DCs to contract domestic spending; consequently, overdraft facilities would have to be contained. In a recessionary environment, it would be up to SCs to raise domestic spending; consequently, overdraft facilities would have to be more expansive than in an inflationary environment.

\section{CONCLUSIONS}

The dollar-based IMS is fragile. This fragility manifests itself in large and long-lived external deficits of the dominant key-currency country. The United States enjoys the privilege of borrowing in the world financial markets at low interest rates without paying a sovereign risk premium commensurate with its level of foreign debt. The interest rate "subsidy," in turn, does not give the United States an incentive to make the necessary policy adjustments to align longterm domestic consumption with long-term domestic output. The end result is that US net foreign debt is growing; with that grows the risk of an implosion of the dollar-based IMS. The inherent weakness of the current IMS is that it relies on an international money that is also a national money: This dual role cannot be easily reconciled because the Fed faces a conflict between pursuing domestic objectives of employment and inflation and maintaining the international public good of a stable money. This conflict is typically resolved in favor of domestic objectives. 
We have argued that the time to fix the IMS is now for the simple reason that radical changes are best made in times of crises. China, the largest creditor country and the most exposed to a possible implosion of the dollar-based IMS has expressed --through the voice of its central bank governor, Zhou Xiaochuan--- the merits of restructuring the IMS around a supernational money. However, for practical reasons, China has advocated the revitalization of SDRs. The G20 leaders have obliged. But the SDR scheme is weak. As presently constituted, SDRs are neither money nor a claim on an international institution; are issued exogenously without any direct consideration to countries' financing needs; and can activate international monies only through bilateral transactions. As supplements to international reserves, the SDRs have failed in the past.

Our preferred solution is the creation of a supernational bank money (SBM) within the institutional setting of a clearing union. This union goes beyond the simple accounting of recording credit and debit entries of SBMs. It is the result of a full-fledged agreement by participating central banks on specific rules of the game, such as size and duration of overdrafts, designation of countries that would have to bear the burden of external adjustment, and coordination of monetary policies. The IMF is the international organization that is best positioned to monitor and "enforce” these rules; not an easy task, yet feasible. Cooperation, even when it is incentive compatible, requires the institutionalization of objectives, ways, and means. The interest of the United States in cooperating would be linked to maintaining and improving the international brand name of the dollar, which would continue to be used as a means of payment and store of value. SBM would be only a substitute (and not a complete replacement) for the dollar in official reserves. The interest of China in cooperating would come firstly from 
the benefits of diversification away from dollar assets and secondly from the larger role the country would play in the international monetary system.

\section{Bibliography}

Ahamed, Liaquat. 2009. Lords of Finance. New York: The Penguin Press.

Alessandrini, Pietro and Michele Fratianni. 2009 forthcoming. Resurrecting Keynes to Stabilize the International Monetary System, Open Economies Review.

Alogoskoufis, G. and R. Portes. 1997. The Euro, the Dollar, and the International Monetary System, in P.R. Masson, TH Krueger, and B.G. Turtelboom (eds.), EMU and the International Monetary System, Washington, D.C.: the International Monetary Fund.

Bank for International Settlements. 2007. Triennial Central Bank Survey: Foreign Exchange and Derivative Market Activity in 2007. Basel, Switzerland. 2009. BIS Quarterly Review, March.

Bergsten, C.F. 1997. The Impact of the Euro on Exchange Rates and International Policy Coordination, in P.R. Masson, TH Krueger, and B.G. Turtelboom (eds.), EMU and the International Monetary System, Washington, D.C.: the International Monetary Fund.

Bernanke, Ben S. 2005. The Global Saving Glut and the U.S. Current Account Deficit, speech delivered for the Sandridge Lecture at the Virginia Association of Economists, Richmond, March 10; www.federalreserve.gov/boarddocs/speeches/2005/200503102/default.htm.

Bernanke, Ben S. 2007. Global Imbalances -Recent Developments and Prospects, Bundesbank Lecture, Berlin, 11 September.

Boughton, James. 2001. Silent Revolution: the International Monetary Fund 1979-1989. Washinton, D.C.: International Monetary Fund.

Campa, Jose, and Linda Goldberg. 2005. "Exchange Rate Pass-Through into Import Prices.” Review of Economics and Statistics 87(4): 679-690.

Chinn, Menzie, and Jeffrey Frankel. 2005. "Will the Euro Eventually Surpass the Dollar as Leading International Reserve Currency?”. NBER Working Paper N. 11510.

Cipolla, Carlo M. 1956. Money, Prices, and Civilization in the Mediterranean World. Princeton, N.J.: Princeton University Press.

Commission on the Role of Gold in the Domestic and International Monetary System. 1982. Report. Washington, D.C.: Government Printing Office.

Despres, Emile, Charles P. Kindleberger, and Walter S. Salant. 1966. The Dollar and World Liquidity: A Minority View." The Economist, February 5, pp. 526-529.

Dooley, Michael P., David Folkerts-Landau and Peter Garber. 2003. An Essay on the Revived Bretton Woods System, NBER Working Paper N. 9971.

Eichengreen, Barry. 1985. Editor's Introduction, in Barry Eichengreen (ed.), The Gold Standard in Theory and History, New York and London: Methuen.

Eichengreen, Barry. 2005. Sterling's Past, Dollar's Future: Historical Perspectives on Reserve Currency Competition. NBER Working Paper 11336. 
Eichengreen, Barry. 2007. Global Imbalances and the Lessons of Bretton Woods. Boston: MIT Press.

Eichengreen, Barry and A. Jeffrey Frankel. 1996.The SDR, Reserve Currencies, and the Future of the International Monetary System, in M. Mussa, J. Boughton, and P. Isard (eds.), The Future of the SDR in Light of Changes in the International Monetary System. Washington, D.C.: International Monetary Fund.

Feldstein, Martin. 1997. The Political Economy of The European Economic and Monetary Union: Political Sources of an Economic Liability, Journal of Economic Perspectives 11 (4): 23- 42.

Flandreau, M. , Le Cacheau, J. and Zumer, F. 1998. Stability Without a Pact? Lessons from the European Gold Standard 1880-1914, CEPR, Discussion Paper Series, No. 1872.

Fratianni, Michele. 1974. The problem of coexistence of SDRs and a reserve currency: a comment, Journal of Money, Credit and Banking, February.

Fratianni, Michele. 2008 forthcoming. Financial crises, safety nets and regulation, Rivista Italiana degli Economisti.

Fratianni, Michele and Andreas Hauskrecht. 1998. From the Gold Standard to a Bipolar Monetary System, Open Economies Review, 1998, 9-S: 609-636.

Fratianni, Michele, Hauskrecht, Andreas and Aurelio Maccario. 1998. Dominant Currencies and the Future of the Euro, Open Economies Review, 1998, 9-S: 467-491. Fratianni

Fratianni, Michele and Paolo Savona. 1974. Un modello esplicativo della tesaurizzazione e degli usi dei diritti speciali di prelievo, Economia Internazionale, n. 1, febbraio.

Friedman, Milton and Anna J. Schwartz. 1982. Monetary Trends in the United States and the United Kingdom: Their Relation to Income, Prices, and Interest Rates, 1867-1975. Chicago: The University of Chicago Press.

Goldberg, Linda, and Cédric Tille. 2006. The International Role of the Dollar and Trade Balance Adjustment. Occasional Paper 71. Washington, D.C.: Group of Thirty.

Gourinchas, Pierre-Olivier and Hélène Rey. 2005. From World Banker to World Venture Capitalist: US External Adjustment and the Exorbitant Privilege, NBER Working aper N. 11563 (August).

IMF (2009), Special Drawing Rights (SDRs), february, available at http://www.imf.org/external/np/exr/facts/sdr.htm

Kenen, Peter B. 1981. The Analytics of a Substitution Account, BNL Quarterly Review, 139, 403-426.

Keynes, John M. 1925. The Economic Consequences of Mr. Churchill. London: L and V. Woolf.

Keynes, John M. 1930. A Treatise on Money, in The Collected Writings of John Maynard Keynes, volume VI, Royal Economic Society. London: MacMillan, 1971.

Keynes, John M. 1943. Proposals for an International Clearing Union, British Government Publication, Cmd.6437, London (April). Reprinted in J. Keith Horsefield ed. (1969), volume III: Documents, pp.19-36.

Kindleberger, Charles P. 1973. The World in Depression, 1929-1939. Berkeley and Los Angeles: University of California Press.

Lindert, Peter H. 1969. Key Currencies and Gold, 1900-1913." Princeton Studies in International Finance, No 24. Princeton, N.J.: Princeton University.

Lopez, Roberto S. 1951. The Dollar of the Middle Ages. Journal of Economic History, 11: 209234.

Machlup, Fritz (1968), Remaking the international monetary system. The Rio Agreement and beyond”, J.Hopkins, Baltimore. 
Micossi, Stefano and Fabrizio Saccomanni. 1981. The Substitution Account: the Problem, the Techniques and the Politics, BNL Quarterly Review, 137:171-189.

Papaioannau, Elias and Richard Portes 2008. Costs and Benefits of Running an International Currency, European Economy, Economic Papers, 348, november.

Portes, R. and H. Rey. 1998. The Emergence of the Euro as an International Currency, Economic Policy 26: 305-343.

Roubini, Nouriel and Brad Setser. 2005. Will the Bretton Woods 2 Regime Unravel Soon? The Risk of a Hard Landing in 2005-2006, unpublished manuscript.

Setser, Brad. 2009. Who Bought all the Treasuries the US Issued in 2008? And Who Will Be the Big Buyers in 2009?,” http://blogs.cfr.org/setser/2009/ Zhou Xiaochuan, the Governor of the People's Bank of China, in a document titled "Reform the International Monetary System,” available at http://www.pbc.gov.cn/english/detail.asp?col=6500\&id=178.

Triffin, Robert. 1960. Gold and the Dollar Crisis. New Haven: Yale University Press.

Xiaochuan, Zhou. 2009. Reform the International Monetary System," available at http://www.pbc.gov.cn/english/detail.asp?col=6500\&id=178. 